\title{
Decomposition of changes in structure and trends in employment in Czechia at NUTS 2 level
}

\author{
Małgorzata Markowska ${ }^{1 *}$ \\ ${ }^{1}$ Wrocław University of Economics, Komandorska 118/120, 53-345 Wrocław, Poland \\ * Corresponding author: malgorzata.markowska@ue.wroc.pl
}

\begin{abstract}
Observing the structure of employment and its trends constitute the fundamental baseline to assess the successes and failures of both national and EU social and economic policies in terms of evaluating effectiveness of support to regions framed by both competitiveness and cohesion issues. The study presents the assessment of structural changes of employment in the system of traditional three economic sectors using the measure of structures dissimilarity along with its decomposition and trends. The Czech NUTS 2 level regions were used for the study and the analysed period covered the years 2008-2014. The $U$ measure of changes in structure of components was applied on data on employment (NACE classification). The results confirmed the current trends of (i) tertiarization in old industrial regions; (ii) the increasing share of employment in the industrial sector shown by some rural regions, and (iii) the growing fragmentation of the spatial pattern of socio-economic development.
\end{abstract}

Key words: structural changes, economy sectors, employment, NUTS 2 level regions

\section{Highlights for public administration, management and planning:}

- The indicator of changes in employment structure at a mesoregional level has been proposed and applied to the Czech Republic.

- The results obtained are confirmed by existing in-depth studies and therefore indicate suitability of the indicator for description of the dominant patterns in employment structure as a basis for cross-country comparative analyses.

Received: 9 Jun 2017 - Received in revised form: 10 Nov 2017 - Accepted: 30 Nov 2017

\section{Introduction}

The turbulent environment and permanent changes form modern economic reality. The change, i.e. the fact that something becomes different than it has been so far results in the modification of some part within the identified entity (Griffin 2005). The following basic dimensions of changes can be distinguished in the context of an economy functioning e.g. (Götz 2012): economic sector system (the share of sectors, branches or sections in generating e.g. GDP), macroeconomic production functions (labour, capital, technology), business prosperity, economic situation and economic climate. Observing changes, detecting their direction, the assessment and measurement of trends constitute an interesting challenge for macro, mezzo and micro scale research. The existing situation in companies, public institutions and business environment, and also the everyday life practice of households have impact on the condition and functioning of regional economy which, indeed, remains closely connected with its macro-environment.

In many regions, as a result of either the dynamics or stagnation of business development, and also, e.g., of the policy carried out by the state (regional) authorities, the direction of structural changes varies, whereas the relevant 
'vectors' sometimes keep changing each consecutive year.

The study discusses the assessment of structural changes in terms of employment in the system of traditional three economic sectors using the measure suggested by Chomątowski \& Sokołowski (1978) and its decomposition by means of $U$ measure application. The Czech Republic NUTS 2 level regions were covered by the study in the period 2008-2014 - due to the availability of comparable data. In order to address the overall assessment of the share of three sectors in the regional employment structure changes, the following questions have to be answered:

- is the average share of the individual sectors different, i.e. statistically is the average $U$ value significantly different from zero?

- is the significant trend observed in share of the observed sectors (i.e. statistically in $U$ values)?

- what is the measure decomposition of structures' dissimilarity performed in accordance with $U$ measure indications?

The study begins with brief theoretical consideration on economic structure and then moves on to the statistical methods used to decompose the trends in employment structure.
Particular attention is devoted to data availability and rationale for the use of NUTS 2 level in the study. Finally, results are presented while pointing out to the major trends in development of employment structure of Czech regions.

\section{Economic structures}

The concept of structure is used in the dual meaning. The first refers to the configuration of points in the multidimensional space, whereas the second one reflects the sequence of non-negative numbers adding up to 1 . Our analysis covers the latter structures (Markowska \& Sokołowski 2016). In our opinion this is the case when the structure presents a certain calculation effect possible only as a result of comparing a part with an entity. The existence of a non-trivial structure is determined by at least two structure components. The structure represents a 'shape' or a form. The actual, rather than just 'calculation' type of changes occur in the values of the structure components - representing 'size', 'quantity', 'value', 'magnitude'. Size changes do not have to alter the changes in shape if the changes of both components present the same proportions. Shape alterations, however, cannot occur without size changes (Penrose 1954; Walesiak 1983; Markowska \& Sokołowski 2016, Markowska 2016).

Table 1 - Changes in structure - hypothetical options (two components) (Source: Markowska 2016)

\begin{tabular}{llll} 
Situation & Components (size: value, quantity) & Remarks \\
(structure) & 1 & 2 & - \\
\hline Stabilization - no changes & no changes & no changes & Both by relatively the same size \\
& increase & increase & \\
decrease & decrease & - \\
Higher share (first & no changes & - \\
component) & no changes & decrease & Higher for the second component \\
& decrease & decrease & Higher for the first component \\
increase & increase & - \\
decrease & no changes & - \\
component) & no changes & increase & Higher for the first component \\
& decrease & decrease & Higher for the second component
\end{tabular}


The assessment of structure changes can result in three options: stabilisation, increase and decrease of a particular component/components share in the entire structure. However, for each of them several variants are possible. Table 1 presents the simplest situation, i.e. for two structure components (e.g. structure by gender or ownership sectors).

For example, the effect of changes assessment, indicating structure stability, can result from the actual absence of changes in both components, but also the simultaneous increase (decrease) of both components by relatively the same value (Markowska 2016).

\section{The assessment of particular structure components' share and its changes}

The study by Markowska \& Sokołowski (2016) presents the measures of structure component share in its changes while comparing structures in two objects (or periods), both in terms of size and shape, which determine the component's share in changes. Therefore, if assumed that changes in structure are caused by size changes, the following measure of component $i$ share in changes of structure can be suggested when comparing structures in two objects / periods / 1 and 2 numbered moments (this numeration is primarily needed for time data). Our analysis covers changes observed in moment 2 against moment 1 (Markowska \& Sokołowski 2016):

$U_{i}=\frac{x_{2 i}-x_{1 i}}{\sum_{i=1}^{m}\left|x_{2 i}-x_{1 i}\right|}$

where:

$i$ - number of the structure component,

$m$ - number of components in the structure,

$x_{1 i}$ - value of $i$-th structure component in the first moment (period),

$x_{2 i}$ - value of $\mathrm{i}$-th structure component in the second moment (period).

The sum of Ui modules equals 1 . The measure takes the value which defines the component share in the changes, as well as the sign informing about the occurring increase or decrease. This measure takes the structure 'size' effect into account.

Table 2 - Statistical Classification of Economic Activities (Source: NACE Rev. 2, 2008)

\begin{tabular}{|c|c|c|c|}
\hline $\begin{array}{l}\text { Section } \\
\text { code }\end{array}$ & Full name & $\begin{array}{l}\text { Section } \\
\text { code }\end{array}$ & Full name \\
\hline A & Agriculture, Forestry and Fishing & K & Financial and Insurance Activities \\
\hline B & Mining and Quarrying & $\mathrm{L}$ & Real Estate Activities \\
\hline C & Manufacturing & M & Professional, Scientific and Technical Activities \\
\hline D & Electricity, Gas, Steam and Air Conditioning Supply & $\mathrm{N}$ & Administrative and Support Service Activities \\
\hline $\mathrm{E}$ & $\begin{array}{l}\text { Water Supply; Sewerage, Waste Management and } \\
\text { Remediation Activities }\end{array}$ & 0 & $\begin{array}{l}\text { Public Administration and Defence; Compulsory } \\
\text { Social Security }\end{array}$ \\
\hline $\mathrm{F}$ & Construction & $\mathrm{P}$ & Education \\
\hline G & $\begin{array}{l}\text { Wholesale and Retail Trade; Repair of Motor Vehicles } \\
\text { and Motorcycles }\end{array}$ & $\mathrm{R}$ & Arts, Entertainment and Recreation \\
\hline $\mathrm{H}$ & Transportation and Storage & $\mathrm{S}$ & Other Service Activities \\
\hline 1 & Accommodation and Food Service Activities & $\mathrm{T}$ & $\begin{array}{l}\text { Activities of Households as Employers; } \\
\text { Undifferentiated Goods- and Services-Producing } \\
\text { Activities of Households for Own Use }\end{array}$ \\
\hline $\mathrm{J}$ & Information and Communication & 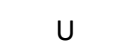 & Activities of Extraterritorial Organisations and Bodies \\
\hline
\end{tabular}


Table 3 - Employment in Czech regions in the years 2008-2014 (thous.) (Based on: Eurostat, 2015)

\begin{tabular}{|c|c|c|c|c|c|c|c|}
\hline \multirow[t]{2}{*}{ Specification } & \multicolumn{7}{|l|}{ Year } \\
\hline & 2008 & 2009 & 2010 & 2011 & 2012 & 2013 & 2014 \\
\hline \multicolumn{8}{|c|}{ Total } \\
\hline Česká republika & 5002.2 & 4934.0 & 4884.9 & 4872.6 & 4890.0 & 4936.9 & 4974.0 \\
\hline Praha & 645.6 & 660.1 & 656.9 & 635.2 & 647.7 & 649.4 & 648.0 \\
\hline Střední Čechy & 599.3 & 601.5 & 602.1 & 610.3 & 623.7 & 626.2 & 633.5 \\
\hline Jihozápad & 594.8 & 582.1 & 573.7 & 575.7 & 572.4 & 576.0 & 580.6 \\
\hline Severozápad & 519.8 & 509.6 & 506.2 & 504.2 & 492.5 & 504.8 & 507.5 \\
\hline Severovýchod & 709.8 & 690.4 & 690.3 & 688.3 & 684.2 & 689.5 & 703.1 \\
\hline Jihovýchod & 784.8 & 770.7 & 770.1 & 766.9 & 769.7 & 792.8 & 795.9 \\
\hline Střední Morava & 579.4 & 562.3 & 542.5 & 550.5 & 556.8 & 554.1 & 556.5 \\
\hline Moravskoslezsko & 568.8 & 557.6 & 543.6 & 540.7 & 542.9 & 544.3 & 549.1 \\
\hline \multicolumn{8}{|c|}{ Agriculture, forestry and fishing } \\
\hline Česká republika & 158.8 & 153.8 & 151.2 & 145.6 & 149.2 & 149.6 & 136.7 \\
\hline Praha & 0.7 & 2.7 & 2.2 & 1.8 & 2.5 & 2.2 & 1.5 \\
\hline Střední Čechy & 18.2 & 17.4 & 18.1 & 17.4 & 16.2 & 17.6 & 15.7 \\
\hline Jihozápad & 31.4 & 27.4 & 31.0 & 29.8 & 28.8 & 27.0 & 27.2 \\
\hline Severozápad & 13.3 & 11.6 & 11.5 & 13.0 & 10.9 & 13.3 & 10.0 \\
\hline Severovýchod & 26.2 & 25.2 & 23.2 & 26.0 & 27.0 & 25.8 & 24.8 \\
\hline Jihovýchod & 38.5 & 35.8 & 32.8 & 28.5 & 31.5 & 33.0 & 31.1 \\
\hline Střední Morava & 18.6 & 22.7 & 22.0 & 18.1 & 20.7 & 19.5 & 15.4 \\
\hline Moravskoslezsko & 11.8 & 11.0 & 10.4 & 11.0 & 11.6 & 11.2 & 11.1 \\
\hline \multicolumn{8}{|c|}{ Industry } \\
\hline Česká republika & 2027.2 & 1903.1 & 1855.7 & 1873.4 & 1864.2 & 1851.9 & 1892.1 \\
\hline Praha & 118.8 & 130.5 & 118.6 & 109.1 & 124.0 & 129.6 & 122.6 \\
\hline Střední Čechy & 241.4 & 227.5 & 221.5 & 218.7 & 223.0 & 212.7 & 216.6 \\
\hline Jihozápad & 254.7 & 238.8 & 233.2 & 243.4 & 239.2 & 242.7 & 243.0 \\
\hline Severozápad & 223.6 & 216.7 & 216.5 & 215.3 & 205.6 & 200.7 & 198.4 \\
\hline Severovýchod & 336.8 & 311.2 & 306.0 & 308.4 & 298.1 & 297.7 & 315.1 \\
\hline Jihovýchod & 332.2 & 302.9 & 294.5 & 296.2 & 300.5 & 306.0 & 311.0 \\
\hline Střední Morava & 265.0 & 239.9 & 233.7 & 246.5 & 243.1 & 242.8 & 257.9 \\
\hline Moravskoslezsko & 254.7 & 235.6 & 231.8 & 235.9 & 230.6 & 219.7 & 227.6 \\
\hline \multicolumn{8}{|c|}{ Services } \\
\hline Česká republika & 2816.2 & 2877.1 & 2878.0 & 2853.6 & 2876.6 & 2935.4 & 2945.2 \\
\hline Praha & 526.1 & 526.9 & 536.1 & 524.3 & 521.2 & 517.6 & 523.9 \\
\hline Střední Čechy & 339.7 & 356.6 & 362.5 & 374.2 & 384.5 & 395.9 & 401.2 \\
\hline Jihozápad & 308.7 & 315.9 & 309.5 & 302.5 & 304.4 & 306.3 & 310.4 \\
\hline Severozápad & 282.9 & 281.3 & 278.2 & 275.9 & 276.0 & 290.8 & 299.1 \\
\hline Severovýchod & 346.8 & 354.0 & 361.1 & 353.9 & 359.1 & 366.0 & 363.2 \\
\hline Jihovýchod & 414.1 & 432.0 & 442.8 & 442.2 & 437.7 & 453.8 & 453.8 \\
\hline Střední Morava & 295.8 & 299.7 & 286.8 & 285.9 & 293.0 & 291.8 & 283.2 \\
\hline Moravskoslezsko & 302.3 & 311.0 & 301.4 & 293.8 & 300.7 & 313.4 & 310.4 \\
\hline
\end{tabular}




\section{Data - source and diversification in Czech regions}

There are several geographical levels in the European Union, at which statistical data are collected and aggregated, later to be used by official public statistics (e.g., Eurostat 2017). NUTS 2 level in the EU consists of more than 270 regions. At this level, the structural funds are allocated and comparative analyses are performed.

Table 4 - The test of mean values against the constant reference value (U measure) - results

\begin{tabular}{crrrr} 
Variable & \multicolumn{1}{l}{ Mean } & $\begin{array}{c}\text { Standard } \\
\text { deviation }\end{array}$ & & $\mathrm{t}$ \\
\hline A1 & 0.0087 & 0.0698 & 0.3054 & 0.7723 \\
I1 & 0.1174 & 0.6776 & 0.4244 & 0.6889 \\
S1 & -0.0262 & 0.4122 & -0.1599 & 0.8822 \\
A2 & -0.0337 & 0.0869 & -0.9504 & 0.3855 \\
I2 & -0.1538 & 0.3765 & -1.0006 & 0.3630 \\
S2 & $\mathbf{0 . 5 6 5 9}$ & $\mathbf{0 . 1 2 0 4}$ & $\mathbf{1 1 . 5 1 2 0}$ & $\mathbf{0 . 0 0 0 1}$ \\
A3 & -0.0549 & 0.1705 & -0.7885 & 0.4661 \\
I3 & -0.0719 & 0.5177 & -0.3404 & 0.7474 \\
S3 & 0.1496 & 0.4868 & 0.7529 & 0.4854 \\
A4 & -0.0336 & 0.2055 & -0.4000 & 0.7057 \\
I4 & -0.3629 & $\mathbf{0 . 3 0 6 4}$ & $-\mathbf{2 . 9 0 1 7}$ & $\mathbf{0 . 0 3 3 7}$ \\
S4 & -0.0422 & 0.6102 & -0.1695 & 0.8720 \\
A5 & -0.0119 & 0.1389 & -0.2099 & 0.8421 \\
I5 & -0.1297 & 0.5845 & -0.5435 & 0.6102 \\
S5 & 0.1873 & 0.4887 & 0.9387 & 0.3910 \\
A6 & -0.1328 & 0.3113 & -1.0452 & 0.3438 \\
I6 & 0.1032 & 0.4909 & 0.5149 & 0.6286 \\
S6 & 0.1783 & 0.4035 & 1.0825 & 0.3284 \\
A7 & -0.0878 & 0.2359 & -0.9113 & 0.4039 \\
I7 & -0.0286 & 0.5607 & -0.1250 & 0.9054 \\
S7 & -0.1328 & 0.4295 & -0.7573 & 0.4830 \\
A8 & -0.0002 & 0.0389 & -0.0098 & 0.9926 \\
I8 & -0.1260 & 0.5346 & -0.5773 & 0.5888 \\
S8 & -0.0340 & 0.5626 & -0.1480 & 0.8882
\end{tabular}

Symbols: 1 / sectors: A - agriculture, I - industry, $\mathrm{S}$ - services; 2/ regions: 1 - Praha, 2 - Střední Čechy, 3 - Jihozápad, 4 Severozápad, 5 - Severovýchod, 6 - Jihovýchod, 7 - Střední Morava, 8- Moravskoslezsko.

It was adopted in the study that the sector of agriculture covers section $A$, the sector of industry - sections $B-E$ and $F$, and the sector of services - sections G-I, J, K, L, M-N, O-Q and R-U. The age group refers to people aged 15-64. Eurostat database constituted the source of statistical data about employment in the particular activity sections in eight Czech NUTS 2 level regions (Regions 2011).

In 2008 the employment in the Czech Republic amounted to slightly more than 5 million, whereas in 2014 it presented the 99,4\% level from $2000-4,97$ million. In three Czech regions the comparison of employment number in the assessed period allows indicating that the level of employment increased in three regions: Strední Čechy (from 599,3 thous. to 633,5 thous.), Jihovýchod (from 754,8 thous. to 795,9 thous.), Praha (from 645,6 thous. to 648,0 thous.), and a decline in the other five regions - down to $96 \%$ of the situation from 2008 in Střední Morava.

The employment in Czech regions ranged from 519,8 thous. (Severozápad) to 784,8 thous. (Jihovýchod) in 2008 and from 507,5 thous. (Severozápad) to 795,9 thous. (Jihovýchod) in 2014 - see tab. 3. Further analyses of regional economic variability in Czechia can be found in (Hampl et al. 2002; Viturka 2005; Hampl 2005; 2007; Blažek 2005; Blažek \& Csank 2007a, 2007b; Hlaváček 2013; Lux \& Horváth 2017), or structural dynamics in (Sorm \& Terrell 2000; Makhija 2003; Tsenkova 2006; Drahokoupil 2009; Koutský 2011; Blažek et al. 2011; Drucker \& Feser 2012; Lux \& Horváth 2017) and regional specialization in (Duranton \& Puga 2000; Ženka \& Čadil 2009; Kemeny \& Storper 2012).

\section{Results and their interpretation}

The below discussion presents the results of seeking answers to the above questions about the possibility of identifying major trends in $U$ measure values and whether the average share (mean $U$ value) is significantly different from zero. Test application for mean value (comparing it to zero) allowed determining whether within the analysed period any significant, focused change in the share of a given structure component was recorded. Due to the fact that data series have few values 0,10 was adopted as the significance level. Taking the obtained results into account a high variation of values should be indicated, not only in the sense of its level, but also its direction (sign). 
Table 4 shows that the results indicating significance were obtained in two cases only (in terms of testing the relevant share in changes).

In Střední Čechy region the employment in services was gradually increasing and exerting the significant impact on the employment structure change. In Severozápad region an average decline in employment was recorded in the studied period and this phenomenon was of major influence on the changes in employment structure. In both cases the impact of "permanently oriented" nature was observed.

Testing trends in measure changes represents the next stage of the study. Estimation results of the trend models and significance testing of slope coefficients are presented in Table 5.

Table 5 - Coefficients of $U$ measure trend for Czech NUTS 2 level regions

\begin{tabular}{|c|c|c|c|c|}
\hline Region & Sector & Intercept & $\begin{array}{l}\text { Slope } \\
\text { coeff. }\end{array}$ & $\begin{array}{l}p \text { value for } \\
\text { the slope } \\
\text { coeff. }\end{array}$ \\
\hline \multirow{3}{*}{ Praha } & A & 0.0996 & -0.0260 & 0.1243 \\
\hline & 1 & 0.3053 & -0.0540 & 0.7793 \\
\hline & $S$ & -0.0200 & -0.0020 & 0.9878 \\
\hline \multirow{3}{*}{$\begin{array}{l}\text { Střední } \\
\text { Čechy }\end{array}$} & A & 0.0407 & -0.0210 & 0.3615 \\
\hline & I & -0.6040 & 0.1287 & 0.1716 \\
\hline & $S$ & 0.5988 & -0.0090 & 0.7827 \\
\hline \multirow{3}{*}{$\begin{array}{l}\text { Jiho- } \\
\text { západ }\end{array}$} & A & 0.0014 & -0.0160 & 0.7383 \\
\hline & 1 & -0.5370 & 0.1328 & 0.3352 \\
\hline & $S$ & -0.4300 & 0.1657 & 0.1740 \\
\hline \multirow{3}{*}{$\begin{array}{l}\text { Severo- } \\
\text { západ }\end{array}$} & A & 0.0081 & -0.0120 & 0.8382 \\
\hline & 1 & -0.5120 & 0.0426 & 0.6186 \\
\hline & $S$ & -0.9410 & 0.2566 & 0.0633 \\
\hline \multirow{3}{*}{$\begin{array}{l}\text { Severo- } \\
\text { východ }\end{array}$} & A & 0.0138 & -0.0070 & 0.8520 \\
\hline & 1 & -0.9320 & 0.2292 & 0.0969 \\
\hline & $S$ & 0.1757 & 0.0033 & 0.9810 \\
\hline \multirow{3}{*}{$\begin{array}{l}\text { Jiho- } \\
\text { východ }\end{array}$} & A & -0.1730 & 0.0114 & 0.8972 \\
\hline & 1 & -0.7480 & 0.2433 & 0.0078 \\
\hline & $S$ & 0.3236 & -0.0420 & 0.7149 \\
\hline \multirow{3}{*}{$\begin{array}{l}\text { Střední } \\
\text { Morava }\end{array}$} & A & 0.1286 & -0.0620 & 0.3234 \\
\hline & 1 & -0.6410 & 0.1750 & 0.2235 \\
\hline & $S$ & -0.0410 & -0.0260 & 0.8287 \\
\hline \multirow{3}{*}{$\begin{array}{l}\text { Moravsko- } \\
\text { slezsko }\end{array}$} & A & -0.0170 & 0.0049 & 0.6537 \\
\hline & 1 & -0.6890 & 0.1610 & 0.2444 \\
\hline & $S$ & -0.2260 & 0.0547 & 0.7298 \\
\hline
\end{tabular}

Symbols: $1 /$ sectors: A - agriculture, $\mathrm{M}$ - industry, S services.
Figures 1 and 2 provide the illustration of results for the data presented in Table 5. The data on fig. 1 show that the significantly growing shares in structure changes, generated by changes in size referred to industry and services only.

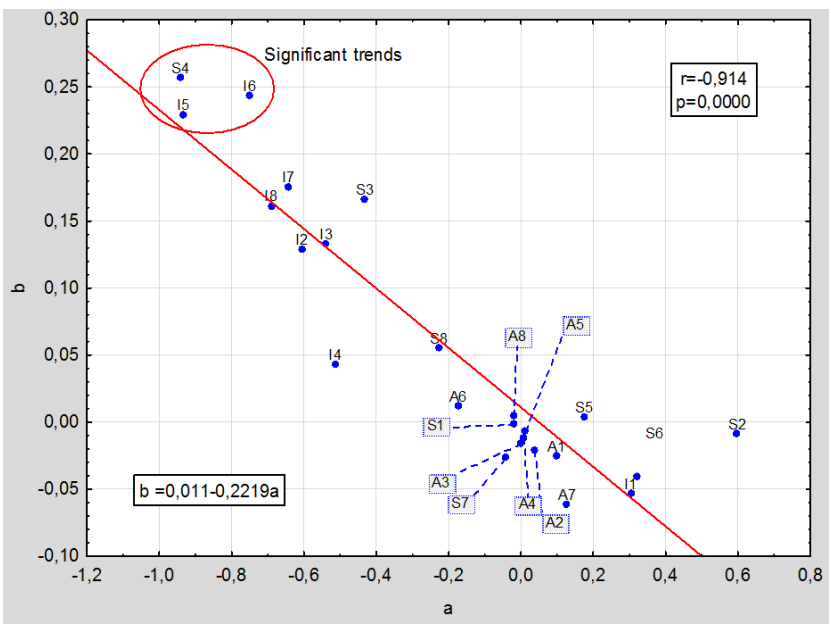

Fig. 1 - Correlation between the intercept and the slope coefficient of the $\mathrm{U}$ measure trend

Symbols: $1 /$ sectors: $\mathrm{A}$ - agriculture, I - industry, $\mathrm{S}$ - services; 2/ regions: 1 - Praha, 2 - Střední Čechy, 3 - Jihozápad, 4 Severozápad, 5 - Severovýchod, 6 - Jihovýchod, 7 - Střední Morava, 8 - Moravskoslezsko.

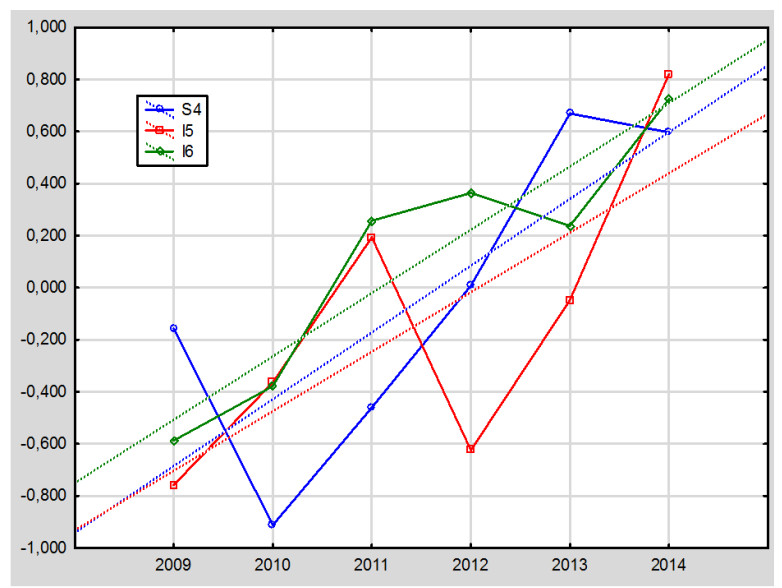

Fig. 2 - Time series and significant trends Symbols: S4 (U4) - services in Severozápad, M5 (P5) industry in Severovýchod, M6 (P6) - industry in Jihovýchod.

Fig. 2 presents the selected trends of shares in structure changes - the significant ones. The illustrated trends show a growing tendency - the share were generally increasing, however, in the 
evaluated period they were also changing, showing ups and downs of the relevant values.

The application of $U$ measure allows identifying the share of particular sectors in the changes of employment structure. It should be kept in mind that the $U$ measure itself does not inform about the changes approached as size. If e.g. $10+10+10$ value structure is assumed, which changes into $20+20+20$, then the shares in changes for every component remain $1 / 3$ (since each of them went up by the same value, i.e. by 10). The change, however, refers to size rather than shape.

The measure of differentiation (dissimilarity) can be decomposed to the particular structure components by applying the following formula:

$$
\mathrm{W}_{\mathrm{i}}=W \cdot\left|U_{i}\right|
$$

This measure shows the change in shape adjusted by the relative change in size. The application i.e. calculation of the measure (2) for changes in employment structure in the sectors of Czech regions, in the period 2008-2014, allowed determining measure decomposition for structures' dissimilarity (measuring these changes intensity) to be followed by trends estimation and their significance testing - see Table 6.

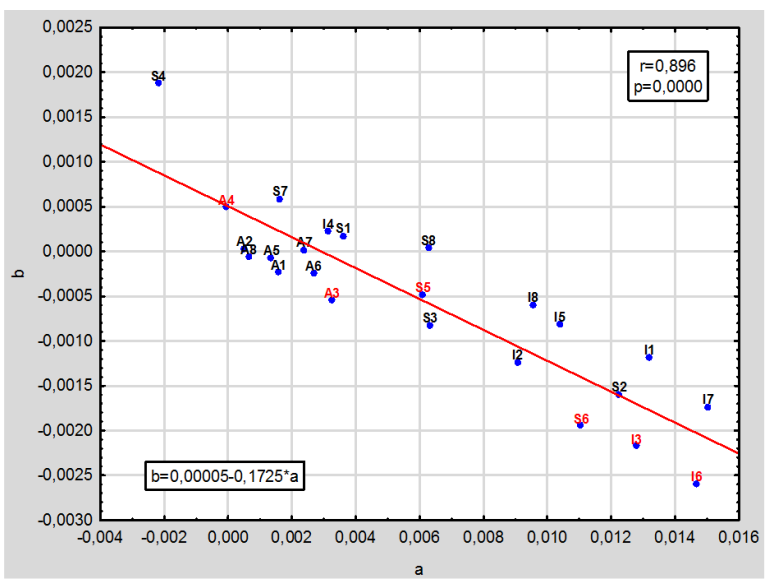

Fig. 3 - Correlation diagram between the coefficients of trend equations $-W_{i}$ measure

Symbols: 1 / sectors: $\mathrm{A}$ - agriculture, $\mathrm{I}$ - industry, $\mathrm{S}$ - services; 2/ regions: 1 - Praha, 2 - Střední Čechy, 3 - Jihozápad, 4 Severozápad, 5 - Severovýchod, 6 - Jihovýchod, 7 - Střední Morava, 8 - Moravskoslezsko.
Fig. 3 presents the correlation diagram between the coefficients of the trend equations. The occurrence of a clear negative correlation between the intercept and the slope coefficient of the analysed trend can be observed. The regions and structure components, characterized by a high starting point in the share of structural changes were, almost always, reducing this share. The regions and components for which the trends presented in Table 6 were statistically significant are marked in red on the figure.

The above observations correspond to the conclusions resulting from Fig. 1.

Table 6 - Coefficients of $W_{i}$ measure trend for Czech regions

\begin{tabular}{|c|c|c|c|c|}
\hline Region & Sector & $\begin{array}{l}\text { Inter- } \\
\text { cept }\end{array}$ & $\begin{array}{l}\text { Slope } \\
\text { coeff. }\end{array}$ & $\begin{array}{l}p \text { value for } \\
\text { the slope } \\
\text { coeff. }\end{array}$ \\
\hline \multirow{3}{*}{ Praha } & $A$ & 0.00160 & -0.00024 & 0.2323 \\
\hline & 1 & 0.01322 & -0.00119 & 0.3882 \\
\hline & $S$ & 0.00362 & 0.00017 & 0.7940 \\
\hline \multirow{3}{*}{$\begin{array}{l}\text { Střední } \\
\text { Čechy }\end{array}$} & A & 0.00053 & 0.00002 & 0.7592 \\
\hline & 1 & 0.00908 & -0.00124 & 0.2622 \\
\hline & $S$ & 0.01225 & -0.00160 & 0.1719 \\
\hline \multirow{3}{*}{ Jihozápad } & A & 0.00327 & -0.00055 & 0.0178 \\
\hline & 1 & 0.01281 & -0.00218 & 0.0683 \\
\hline & S & 0.00633 & -0.00083 & 0.1389 \\
\hline \multirow{3}{*}{$\begin{array}{l}\text { Severo- } \\
\text { západ }\end{array}$} & A & -0.00004 & 0.00049 & 0.0460 \\
\hline & 1 & 0.00316 & 0.00022 & 0.8448 \\
\hline & $S$ & -0.00220 & 0.00187 & 0.1403 \\
\hline \multirow{3}{*}{$\begin{array}{l}\text { Severo- } \\
\text { východ }\end{array}$} & A & 0.00137 & -0.00008 & 0.5893 \\
\hline & 1 & 0.01041 & -0.00082 & 0.6809 \\
\hline & $S$ & 0.00611 & -0.00049 & 0.0783 \\
\hline \multirow{3}{*}{ Jihovýchod } & A & 0.00270 & -0.00025 & 0.3757 \\
\hline & I & 0.01470 & -0.00260 & 0.1180 \\
\hline & $S$ & 0.01107 & -0.00195 & 0.0471 \\
\hline \multirow{3}{*}{$\begin{array}{l}\text { Střední } \\
\text { Morava }\end{array}$} & A & 0.00240 & 0.00001 & 0.9889 \\
\hline & I & 0.01506 & -0.00174 & 0.4851 \\
\hline & $S$ & 0.00164 & 0.00058 & 0.4471 \\
\hline \multirow{3}{*}{$\begin{array}{l}\text { Moravsko- } \\
\text { slezsko }\end{array}$} & A & 0.00067 & -0.00007 & 0.2411 \\
\hline & 1 & 0.00957 & -0.00060 & 0.7153 \\
\hline & $S$ & 0.00628 & 0.00003 & 0.9760 \\
\hline
\end{tabular}

Symbols: 1 / sectors: $\mathrm{A}$ - agriculture, I-industry, $\mathrm{S}$ - services.

The significant trends, however, are not grouped as it takes place in case of $U$ measure, since not just the share in changes, but also the effect of this share is considered here, which results from 
the overall structure transformations (rather than this particular component only).

\section{Conclusions}

The implementation of both intraregional and interregional policy in the turbulent and changing environment requires an ongoing observation along with flexible approach and adjustment to the occurring changes. In terms of structural changes in employment, the conclusions confirm the three basic trends: (a) the significance of tertiarization in old industrial regions in Czechia, and effect of changes in industry to exportoriented, low-value production (Ženka et al. 2015); (b) the increasing share of employment in the industrial sector shown by some rural regions (Hruška 2015 Ed.); and (c) the growing fragmentation of the spatial pattern of socioeconomic development (cf. Blažek \& Netrdová 2012).

It seems that in case of the job market, apart from determining both unemployment and employment rate, presented in various perspectives (e.g. by gender or age), the identification of changes occurring in employment structure - both in terms of shape and scale - represents an indispensable process for e.g. an effective allocation of funds and the properly carried out educational policy.

The approach suggested in the presented article allows detecting basic structural trends, which turn out extensively helpful in the course of the decision making process and offer a valuable supporting tool in monitoring the changes which take place on the regional job market.

\section{Acknowledgements}

The paper is financed by the National Science Centre: 2015/17/B/HS4/01021

\section{References}

Blažek J (2005) Trends to regional disparities in the Czech Republic in pre-accession period in the European context. Geographia Polonica 78(2): 91-106.

Blažek J, Csank P (2007a) Nová fáze regionálního rozvoje v ČR? Sociologický časopis/Czech Sociological Review 43(5): 945-965.
Blažek J, Csank P (2007b) The West-East gradient and regional development: the case of the Czech Republic. In: Acta Universitatis Carolinae Geographica 40(1-2): 89-108.

Blažek J, Netrdová P (2012) Aktuální tendence lokální diferenciace vybraných socioekonomických jevů v Česku: směřuje vývoj $k$ větší mozaikovitosti prostorového uspořádání? Geografie 117: 266-288.

Blažek J, Žížalová P, Rumpel P, Skokan K (2011) Where does the knowledge for knowledge-intensive industries come from? The case of biotech in Prague and ICT in Ostrava. European Planning Studies 19: 1277-1303.

Chomątowski S, Sokołowski A (1978) Taksonomia struktur (The taxonomy of structures). Przegląd Statystyczny (The Statistical Review) 2: 217-226.

Drahokoupil J (2009) After transition: Varieties of political-economic development in Eastern Europe and the former Soviet Union. Comparative European Politics 7: 279-298.

Drucker J, Feser E (2012) Regional industrial structure and agglomeration economies: An analysis of productivity in three manufacturing industries. Regional Science and Urban Economics 42: 1-14.

Duranton G, Puga D (2000) Diversity and specialisation in cities: Why, where and when does it matter? Urban Studies 37: 533-555.

Eurostat (2015) Regional statistics by NUTS classification (Ifst_r_Ife2en2) http://ec.europa.eu/ eurostat/web/regions/data/database

Eurostat (2017) Employment statistics - statistics explained. http://ec.europa.eu/eurostat/statisticsexplained/index.php/Employment_statistics

Götz M (2012), Zarządzanie zmianą gospodarczą w regionie: przesłanki, podejścia, przykłady (Managing an economic change in a region: reasons, approaches, examples). Paper presented at the conference entitled: „Przewidywanie, planowanie i zarządzanie zmianą gospodarczą" ("Anticipating, planning and managing an economic change") http://www.ankieter.com.pl/pdf/M.GoetzZarzadzanie-zmiana-gospodarcza-w-regionie26.07.12.pdf (downloaded: 5th May 2016).

Griffin RW (2005) Podstawy zarządzania organizacjami (Basics in managing organizations). PWN Scientific Publishers, Warsaw.

Hampl M (2005) Geografická organizace společnosti v České republice: transformační procesy a jejich obecný kontext. Faculty of Science, Charles University, Prague. Hampl M (2007) Regionální diferenciace současného socioekonomického vývoje v České republice. 
Sociologický časopis/Czech Sociological Review 43(5): 889-910.

Hampl M et al (2002) Regionální vývoj: specifikace české transformace, evropská integrace a obecná teorie. Faculty of Science, Charles University, Prague.

Hlaváček P (2013) Vývoj a adaptabilita regionálních ekonomik $v$ České republice $v$ postransformačním období. In: Proceedings from XVI. mezinárodní kolokvium o regionálních vědách, Brno: Masarykova univerzita, pp. 42-50.

Hruška V (ed.) (2015) Post-agricultural rural space of the Visegrad countries: economies, entrepreneurship and policies. Studia Obszarów wiejskich / Rural studies 39.

Kemeny T, Storper M (2012) Specialization and Regional Economic Development. SERC Discussion Papers 0121. London: Spatial Economic Research Centre, LSE.

Kostelecký T, Patočková V, Vobecká J (2007) Kraje v České republice - existují souvislosti mezi ekonomickým rozvojem, sociálním kapitálem a výkonem krajských vlád? Sociologický časopis/Czech Sociological Review 43(5): 911-943.

Koutský J (2011) Staré průmyslové regiony - vývojové tendence, možnosti rozvoje. PhD thesis. Ústí nad Labem:University of J.E. Purkyně.

Lux G., Horváth G. (eds) (2017), The Routledge Handbook to Regional Development in Central and Eastern Europe, Routledge, New York.

Makhija MV (2003) The value of restructuring in emerging economies: the case of the Czech Republic. Strategic Management Journal 25(3): 243-267.

Markowska M (2016) Identyfikacja znaczenia krajów w gospodarce UE z wykorzystaniem miary dekompozycji zmian struktury (The identification of countries' significance in the EU economy using the decomposition measure of changes in structure). Research Journal of Cracow University of Economics, Cracow 9 (957).

Markowska M, Sokołowski A (2016) Metoda dekompozycji zmian struktury (Decomposition method of changes in structure). Prace Komisji Geografii Przemysłu Polskiego Towarzystwa Geograficznego, (The Studies of the Industrial Geography Commission of the Polish Geographical Society), Cracow 30(3): 2532.

NACE Rev. 2. Statistical classification of economic activities in the European Community, (2008), Methodologies and Working papers. European Communities, Luxembourg.
Novák V, Vokoun M, Stellner F, Vochozka M (2016) Institutional Analysis of the Contemporary Regional Labour Market in the Czech Republic. E+M Ekonomie a Management 19(3): 4-19.

Penrose LS (1954) Distance, size and shape. Annals of Eugenics 18: 337-343.

Regions in the European Union. Nomenclature of territorial unit for statistics NUTS 2010/EU-27, (2011), Series: Methodologies and Working Papers, European Commission, Luxembourg.

Sorm V, Terrell K (2000) Sectoral Restructuring and Labor Mobility: A Comparative Look at the Czech Republic. Journal of Comparative Economics 28(3): 431-455.

Tsenkova S (2006) Beyond transitions: Understanding urban change in postsocialist. In: Tsenkova S, NedovićBudić Z (eds.) The Urban Mosaic of Post-Socialist Europe. Springer, Heidelberg, pp. 21-50.

Viturka M (2005) Evaluation of Development Position of Czech regions in the Context of the EU Territory. European Spatial Research and Policy 11(2): 85-105.

Walesiak M (1983) Podobieństwo wielkości (skali) oraz kształtu (formy) w złożonych badaniach strukturalnych (The similarity of size (scale) and shape (form) in complex structural research). Wiadomości Statystyczne (Statistical News) 3: 26-28.

Ženka J, Novotný J, Slach O, Květoň V (2015) Industrial specialization and economic performance: A case of Czech microregions. Norsk Geografisk Tidsskrift Norwegian Journal of Geography 69(2): 67-79.

Ženka J, Čadil V (2009) Regional distribution of technology-intensive manufacturing industries in the Czech Republic with an accent on risk of delocalization. Prague Economic Papers 1: 61-77. 